\title{
IMMUNOGENICITY OF THREE RECOMBINANT HEPATITIS B VACCINES ADMINISTERED TO STUDENTS IN THREE DOSES CONTAINING HALF THE ANTIGEN AMOUNT ROUTINELY USED FOR ADULT VACCINATION
}

\author{
José Luís da Silveira BALDY(1), Gerson Zanetta de LIMA(1), Helena Kaminami MORIMOTO(1), Edna Maria Vissoci REICHE(1), Tiemi MATSUO(1),
} Edlivia Dias de MATTOS(2) \& Luci Cristina Pulga SUDAN(2)

\begin{abstract}
SUMMARY
We evaluated the immunogenicity of three recombinant hepatitis B vaccines, one Brazilian (Butang, Instituto Butantan) and two Korean vaccines (Euvax-B, LG Chemical Ltd. and Hepavax-Gene, Greencross Vaccine Corp.), administered intramuscularly to students aged 17 to 19 years in three 10 - $\mu$ g doses (corresponding to half the amount of antigen routinely used for adult vaccination) at intervals of one month between the first and second dose, and of four months between the second and third dose. A total of 316 students nonreactive for any serological marker of hepatitis B virus infection were vaccinated: 77 (24.4\%) with the Butang vaccine, 71 (22.5\%) with Euvax-B, 85 (26.9\%) with Hepavax-Gene and, for comparison, 83 (26.2\%) with Engerix-B (GlaxoSmithKline), whose efficacy in young adults at the dose used here has been confirmed in previous studies. Similar seroconversion rates (anti-HBs $>10 \mathrm{mIU} / \mathrm{mL}$ about one month after application of the third dose) were obtained for the Butang, Euvax-B, Hepavax-Gene and Engerix-B vaccines (96.2\%, 98.6\%, 96.5\% and 97.6\%, respectively). The frequency of good responders (anti-HBs $>100 \mathrm{mIU} / \mathrm{mL}$ ) was also similar among students receiving the four vaccines $(85.8 \%, 91.6 \%, 89.4 \%$ and $89.2 \%$, respectively). The geometric mean titers (GMT) of anti-HBs about one month after the third dose obtained with these vaccines were $727.78 \pm 6.46 \mathrm{mIU} / \mathrm{mL}, 2009.09 \pm 7.16 \mathrm{mIU} / \mathrm{mL}$, $1729.82 \pm 8.85 \mathrm{mIU} / \mathrm{mL}$ and $2070.14 \pm 11.69 \mathrm{mIU} / \mathrm{mL}$, respectively. The GMT of anti-HBs induced by the Euvax-B and Engerix-B vaccines were higher than those obtained with the Butang vaccine $(\mathrm{p}<0.05)$; this difference was not significant when comparing the other vaccines two-by-two. No spontaneous adverse effects attributable to the application of any dose of the four vaccines were reported.
\end{abstract}

KEYWORDS: Recombinant hepatitis B vaccines; Immunogenicity; Adverse effects.

\section{INTRODUCTION}

Recombinant vaccines against hepatitis B licensed in Brazil by the Ministry of Health possess widely confirmed immunogenicity when applied in the schemes standardized by the "Programa Nacional de Imunizações" (National Immunization Program, NIP). In the case of some of these vaccines (Engerix-B, GlaxoSmithKline, and Recombivax, Merck Sharp \& Dohme), it has been demonstrated that half the dose usually indicated for adults yields similar seroconversion rates in persons younger than 20 years ${ }^{2,3,7,8,10}$. However, no studies are available demonstrating the immunogenicity of other recombinant hepatitis B vaccines with a similar composition and obtained by the same methods when the same dose is applied to individuals aged 12 to 19 years.

In a message sent on January 1, 2001 to the State Coordinators, the General Coordination Board of the Immunization Program of the National Health Foundation of the Ministry of Health communicated that "the present hepatitis B vaccine scheme recommended by the NIP is $10 \mu \mathrm{g}$ in $0.5 \mathrm{~mL}$ (Engerix-B - SmithKline Beecham) for individuals from birth until 20 years of age". Since the Ministry of Health intends to recommend the use of other recombinant hepatitis B vaccines available through the NIP for this age group at this dose (which corresponds to half the antigen amount indicated for adults) - using the same scheme of three doses administered intramuscularly at an interval of one month between the first and second dose and of five months between the second and third -, assessment of the immunogenicity of this vaccination scheme for another recombinant vaccines in individuals younger than 20 years becomes necessary.

The objective of the present study was to determine the immunogenicity of three recombinant hepatitis B vaccines available through the NIP in susceptible individuals younger than 20 years, by administering intramuscularly three doses containing half the amount of antigen habitually employed in adult vaccination using a scheme similar to that adopted by the NIP. 


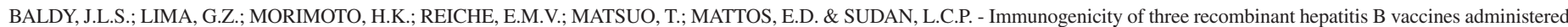
to students in three doses containing half the antigen amount routinely used for adult vaccination. Rev. Inst. Med. trop. S. Paulo, 46(2):103-107, 2004.

\section{PATIENTS AND METHODS}

The study was conducted during the period from February 2001 to April 2002 on students enrolled in first-year courses given at Universidade Estadual de Londrina (UEL), located in the municipality of Londrina, Paraná, Brazil, and at Universidade Norte do Paraná (UNOPAR), which comprises four campuses, three located in the municipality of Londrina and one in the municipality of Arapongas, $39 \mathrm{~km}$ from Londrina.

The following recombinant hepatitis $B$ vaccines were included in the study: Butang (Instituto Butantan, Brazil), Euvax-B (LG Chemical Ltd., Korea), Hepavax-Gene (Greencross Vaccine Corp., Korea) and, for comparison of the results, Engerix-B (GlaxoSmithKline, England), whose immunogenicity in individuals aged 11 to 19 years has already been demonstrated by applying half the dose used for adults in a threedose scheme $(0,1 \text {, and } 6 \text { month scheme })^{2,7,10}$.

The study was approved by the Research Ethics Committee of Hospital Universitário Regional do Norte do Paraná, UEL, and by the Research Board of the Research and Postgraduation Coordination Committee of this University, with these decisions being approved by the Nursing President's Office and Board of UNOPAR.

The proposal of the study was to administer intramuscularly in the deltoid region one of the four vaccines in three $10 \mu \mathrm{g}$ doses in a volume of $0.5 \mathrm{~mL}$ (with $20 \mu \mathrm{g}$ in $1.0 \mathrm{~mL}$ corresponding to the amount of antigen used for adult vaccination for all vaccines) to 100 students using a 0,1 , and 5 month scheme. Assuming that the efficacy of these vaccines (seroconversion) is at least $90 \%$ and that the difference in the number of students included in each group is not higher than $10 \%$, the minimum number of students to be vaccinated, i.e., who should receive each vaccine, was calculated to be 71 per group using the statistical methods mentioned at the end of this section. Due to contingencies related to the dates of the academic year and vacation periods of the students, a 0,1 , and 5-month vaccination scheme was chosen (similar to the 0,1 , and 6month scheme officially adopted by the NIP).

All students younger than 20 years enrolled in UEL and UNOPAR courses received a written invitation to participate in the study and to attend the lectures on hepatitis B and on the importance of vaccination against this disease given by the authors.

The students who adhered to the study answered a standard questionnaire containing data regarding identification, address, a history of hepatitis (hepatitis B in particular), hepatitis B vaccination, blood donation, blood transfusion during the previous six months, other diseases, and continuous drug treatment.

Students who declared to be younger than 20 years and who signed an informed consent form were included in the study. The reported age was confirmed by presentation of an identification document at the time of application of the first or second vaccine dose, with individuals who had completed 20 years at the time of application of the first dose being excluded from the study. Also excluded were students who had been vaccinated at least once against hepatitis $B$, individuals with chronic debilitating disease, diabetes mellitus, anemia, chronic renal failure or some type of immunodepression, and students taking corticosteroids and/or other immunosuppressive drugs. After the students had answered the questionnaire and blood was collected, the subjects were asked to choose a card from a randomly mixed pack of cards previously identified by an equal number of the letters A, B, C and D, each corresponding to one of the four vaccines. Only two researchers knew which letter corresponded to which vaccine, but none of them participated in the serological tests or statistical analysis of the results; the vaccine code was only revealed to the entire research team at the beginning of the preparation of the report for the present article.

Immediately before application of the first vaccine dose, $5 \mathrm{ml}$ blood was collected from the vein of the anterior side of the forearm from all students included in the study for determination of the following markers of hepatitis B virus infection: HBsAg, anti-HBs and anti-HBc using a microparticle enzyme immunoassay (MEIA; Axsym Abbott). Students who were reactive to $\mathrm{HBsAg}$ and/or anti-HBc were referred for specialized medical evaluation and anti-HBs-positive individuals were considered to be immune and received a detailed explanation about why they did not require vaccination.

Thus, before application of the second dose, with the results of the serological tests being available, students who were found to be positive for at least one of the cited markers (anti-HBs, HBsAg or anti-HBc) were excluded. During the study, individuals who did not return for application of the second or third dose or for collection of the second blood sample were also excluded.

One month after application of the third vaccine dose, a second venous blood sample was collected from all vaccinees for a new determination of the same serological markers of hepatitis $\mathrm{B}$ virus infection (HBsAg, anti-HBs and anti-HBc) by the same technique (MEIA, Axsym Abbott). Anti-HBs titers were interpreted based on data reported in the literature ${ }^{5,6}:<10 \mathrm{mIU} / \mathrm{mL}=$ non-reactive (non-responders); $\geq 10$ $\mathrm{mIU} / \mathrm{mL}=$ reactive; 10 to $100 \mathrm{mIU} / \mathrm{mL}=$ reactive (poor responders) and $>100 \mathrm{mIU} / \mathrm{mL}=$ reactive (good responders).

All vaccinated students were asked to inform one of the coordinators of the study about local (pain, local redness or nodule formation) or systemic adverse effects (fever, headache or any other symptom), which occurred after application of the vaccine (in the case of intense local pain, fever or headache, the students were instructed to take 30 drops of paracetamol every 6 hours until they would contact one of the researchers). On the occasion of a return for receiving the new vaccine dose or for collection of the second blood sample, the students were also asked to inform the team about the occurrence of signs and symptoms attributable to vaccination.

Serum geometric mean titers (GMT) of anti-HBs obtained for each vaccine group, quantified about one month after the vaccination scheme was completed, were compared by analysis of variance, using the F-test to determine the equality of means. When a significant difference was observed between titers, the Tukey test was used for pairwise comparison of the GMT obtained for each vaccine. The relative frequencies of good and poor responders to the vaccines were compared by Pearson's chisquare test. The level of significance adopted for all tests was 5\% ( $p<$ 0.05). The statistical analyses were performed using the SAS - Statistical Analysis System program (SAS Institute Inc., 1986) ${ }^{9}$ and the sample size was determined using the nQuery Advisor program ${ }^{4}$. 


\section{RESULTS}

The present study included 955 students, 248 from UEL and 707 from UNOPAR; $615(64.4 \%)$ were females and 339 (35.5\%) were males.

Of the 955 students who underwent the serological tests, one $(0.1 \%)$ showed HBsAg at a low titer and was not reactive to anti-HBc, $37(3.9 \%)$ were positive for serum anti-HBs (11 of them were also positive for anti-HBc, i.e., anti-HBs alone was detected in 26$)$, and two $(0.2 \%)$ were positive for serum anti-HBc. These 40 students were excluded from the group to be vaccinated. A new blood sample for repetition of the serological tests was obtained from the student who showed a weak reaction to HBsAg and who was negative for anti-HBc. The following individuals were also excluded: 219 students who failed to return on the day of application of the second (53 students) and third (166 students) vaccine dose; 115 students who received the three doses but failed to return for collection of the second blood sample about one month after the third vaccine dose; four students whose vaccine type applied in the first dose could not be identified due to the lack of information on the individual chart; 13 because of age (it was confirmed during the study that these individuals had already completed 20 years on the day of application of the first dose), and 259 students initially selected to receive the total dose $(20 \mu \mathrm{g})$ of the Engerix-B (133 students selected by drawing lots) and Butang vaccines (126 students selected by drawing lots), most of them (177) enrolled at the Arapongas campus of UNOPAR. Most students from this campus did not respond to the invitation due to vacation periods and, therefore, the minimum number of participants required for these two groups (71 per group) was not reached. For this reason, the three $20 \mu \mathrm{g}$ dose regimen was not evaluated and the 259 students were excluded from the study. It should be noted that 11 of these 259 students were among the 40 individuals excluded due to the reason mentioned at the beginning of this paragraph. In addition, 190 of the 248 students from UEL who received the first vaccine dose were excluded, i.e., only 58 completed the study, because of the strike of teachers and technicaladministrative employees of this university which lasted throughout the study. In summary, 639 (66.9\%) of the 955 initially selected students were excluded from the study due to the reasons mentioned earlier.

Vaccination against hepatitis B was indicated for 915 students who were negative for all serological markers tested and who orally declared to be younger than 20 years on the day of application of the first vaccine dose. Initially, four groups of these students were selected by drawing lots in order to receive the three $10 \mu \mathrm{g}$ doses of the following vaccines: Butang ( $\mathrm{N}=167)$, Euvax-B $(\mathrm{N}=176)$, Hepavax-Gene $(\mathrm{N}=176)$, and
Engerix- $B(\mathrm{~N}=173)$. Due to the reasons mentioned earlier, only 316 of these students received the three $10 \mu \mathrm{g}$ doses of the vaccines and were submitted to serological tests about one month after application of the third dose, including $258(81.6 \%)$ students from UNOPAR and 58 (18.4\%) from UEL. Twenty-one $(6.6 \%)$ students were 17 years old, 126 (39.9\%) 18 years old, and $169(53.5 \%) 19$ years old. The mean age of the vaccinees was $18.5 \pm 0.62$ years; $223(70.6 \%)$ were females and 93 (29.4\%) were males. Table 1 shows the distribution of the students according to the vaccine received.

The interval between application of the first and second dose ranged from 26 to 37 days for all vaccines, with a mean of $32.6 \pm 2.48$ days. The interval between application of the second and third dose ranged from 96 to 149 days for all vaccines $(121.1 \pm 4.02$ days). The interval between application of the third dose and collection of the second blood sample for the serological tests ranged from 23 to 51 days for all vaccines $(29.6 \pm 4.46$ days $)$

$\mathrm{HBsAg}$ and anti-HBc were not detected in the second serum sample of vaccinated individuals who presented seroconversion (serum antiHBs titers $\geq 10 \mathrm{mIU} / \mathrm{mL}$ ).

The vaccinees did not report any spontaneous complaints regarding local or systemic adverse effects after each vaccine application.

Table 2 shows the distribution of students receiving the different vaccines according to serum anti-HBs titers about one month after the application of the third dose.

Results obtained with the Butang vaccine: The interval between application of the first and second Butang dose ranged from 28 to 37

Table 1

Student distribution according to the vaccine administered

\begin{tabular}{lcc}
\hline Vaccine applied & \multicolumn{2}{c}{ Vaccinated students } \\
& $\mathrm{N}$ & $\%$ \\
\hline Butang (Instituto Butantan, Brasil) & 77 & 24.4 \\
Euvax-B (LG Chemical Ltd., Korea) & 71 & 22.5 \\
Hepavax-Gene (Greencross & 85 & 26.9 \\
Vaccine Corp., Korea) & & \\
Engerix-B (GlaxoSmithKline, England) & 83 & 26.2 \\
Total & 316 & 100.0 \\
\hline
\end{tabular}

Table 2

Distribution of the students who received the Butang, Euvax-B, Hepavax-Gene and Engerix-B vaccines according to serum anti-HBs titers one month after the third dose

\begin{tabular}{|c|c|c|c|c|c|c|c|c|}
\hline \multirow{2}{*}{$\begin{array}{l}\text { Serum anti-HBs titer } \\
\text { after the third dose } \\
(\mathrm{mIU} / \mathrm{mL})\end{array}$} & \multicolumn{2}{|c|}{ Butang } & \multicolumn{2}{|c|}{ Euvax-B } & \multicolumn{2}{|c|}{ Hepavax-Gene } & \multicolumn{2}{|c|}{ Engerix- $B$} \\
\hline & $\mathrm{n}$ & $\%$ & $\mathrm{n}$ & $\%$ & $\mathrm{n}$ & $\%$ & $\mathrm{n}$ & $\%$ \\
\hline$<10$ & 3 & 3.8 & 1 & 1.4 & 3 & 3.5 & 2 & 2.4 \\
\hline $10|-| 100$ & 8 & 10.4 & 5 & 7.0 & 6 & 7.1 & 7 & 8.4 \\
\hline $100-1000$ & 28 & 36.4 & 19 & 26.8 & 18 & 21.2 & 19 & 22.9 \\
\hline$>1000$ & 38 & 49.4 & 46 & 64.8 & 58 & 68.2 & 55 & 66.3 \\
\hline Total & 77 & 100.0 & 71 & 100.0 & 85 & 100.0 & 83 & 100.0 \\
\hline
\end{tabular}




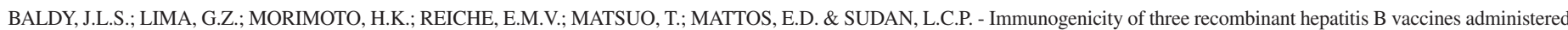
to students in three doses containing half the antigen amount routinely used for adult vaccination. Rev. Inst. Med. trop. S. Paulo, 46(2):103-107, 2004.

days $(33.2 \pm 2.05)$, the interval between application of the second and third dose ranged from 117 to 139 days $(120.5 \pm 2.88)$, and the interval between application of the third dose and collection of the second blood sample ranged from 23 to 44 days $(28.8 \pm 3.07)$. The GMT of anti-HBs in students who received this vaccine was $727.78 \pm 6.46 \mathrm{mIU} / \mathrm{mL}$.

Results obtained with the Euvax-B vaccine: The interval between application of the first and second Euvax-B dose ranged from 27 to 37 days $(32.1 \pm 2.65)$, the interval between application of the second and third dose ranged from 96 to 139 days $(121.3 \pm 5.01)$, and the interval between application of the third dose and collection of the second blood sample ranged from 23 to 51 days $(30.7 \pm 5.76)$. The GMT of anti-HBs in students who received this vaccine was $2009.09 \pm 7.16 \mathrm{mIU} / \mathrm{mL}$.

Results obtained with the Hepavax-Gene vaccine: The interval between application of the first and second Hepavax- $B$ dose ranged from 27 to 35 days $(32.5 \pm 2.58)$, the interval between application of the second and third dose ranged from 118 to 138 days $(121.1 \pm 3.32)$, and the interval between application of the third dose and collection of the second blood sample ranged from 23 to 49 days $(29.6 \pm 4.00)$. The GMT of anti-HBs in students who received this vaccine was $1729.82 \pm$ $8.85 \mathrm{mIU} / \mathrm{mL}$.

Results obtained with the Engerix-B vaccine: The interval between application of the first and second Engerix- $B$ dose ranged from 26 to 36 days $(32.7 \pm 2.53)$, the interval between application of the second and third dose ranged from 118 to 149 days $(121.4 \pm 4.59)$, and the interval between application of the third dose and collection of the second blood sample ranged from 23 to 49 days $(29.6 \pm 4.62)$. The GMT of anti-HBs in students who received this vaccine was $2070.14 \pm 11.69 \mathrm{mIU} / \mathrm{mL}$.

Comparison of the results obtained with the four vaccines: Table 3 shows the distribution of students who received the four vaccines according to serum anti-HBs titers about one month after administration of the third dose. The seroconversion rate, and GMT and standard deviation of serum anti-HBs about one month after application of the third dose obtained with three $10 \mu \mathrm{g}$ doses of the four vaccines studied $(0,1$, and 5 month scheme) are shown in Table 4. Statistical analysis of log transformed data demonstrated higher GMT of anti-HBs in students vaccinated with the Euvax-B and Engerix-B vaccines when compared pairwise than those induced with the Butang vaccine $(\mathrm{p}<0.05)$, while pairwise comparison of the other vaccines showed no differences in GMT of anti-HBs.

A similar frequency of good responders (anti-HBs $>100 \mathrm{mIU} / \mathrm{mL}$ ) was observed for all four vaccines studied $(p>0.05)$.

Table 3

Distribution of all students who received the four vaccines according to serum anti-HBs titers about one month after the third dose

\begin{tabular}{crc}
\hline \multirow{2}{*}{$\begin{array}{c}\text { Anti-HBs titer } \\
(\mathrm{mIU} / \mathrm{mL})\end{array}$} & \multicolumn{2}{c}{ Vaccinated students } \\
\hline$<10$ & $\mathrm{~N}$ & $\%$ \\
$10|-| 100$ & 9 & 2.8 \\
$100-\mid 1000$ & 26 & 8.2 \\
$>1000$ & 84 & 26.6 \\
Total & 197 & 62.3 \\
\hline
\end{tabular}

Table 4

Seroconversion rate, geometric mean titer (GMT) and standard deviation of anti-HBs one month after application of three $10 \mu \mathrm{g}$ doses $(0,1$, and 5 month scheme) of four recombinant hepatitis B vaccines

\begin{tabular}{lccc}
\hline Vaccine studied & $\begin{array}{c}\text { Seroconversion } \\
\text { rate } \\
\%\end{array}$ & $\begin{array}{c}\text { GMT } \\
(\mathrm{mIU} / \mathrm{mL})\end{array}$ & $\begin{array}{c}\text { Standard } \\
\text { deviation } \\
(\mathrm{mIU} / \mathrm{mL})\end{array}$ \\
\hline $\begin{array}{l}\text { Butang } \\
(\mathrm{n}=77)\end{array}$ & 96.2 & 727.78 & 6.46 \\
$\begin{array}{l}\text { Euvax-B } \\
(\mathrm{n}=71)\end{array}$ & 98.6 & 2009.09 & 7.16 \\
$\begin{array}{l}\text { Hepavax-Gene } \\
(\mathrm{n}=85)\end{array}$ & 96.5 & 1729.82 & 8.85 \\
$\begin{array}{l}\text { Engerix-B } \\
(\mathrm{n}=83)\end{array}$ & 97.6 & 2070.14 & 11.69 \\
$\begin{array}{l}\text { Overall mean } \\
(\mathrm{n}=316)\end{array}$ & 97.2 & 1520.55 & 8.79 \\
\hline
\end{tabular}

\section{DISCUSSION AND CONCLUSION}

No investigations are available in the literature evaluating the immunogenicity of the three recombinant vaccines studied here - one Brazilian vaccine (Butang, Instituto Butantan, São Paulo, Brazil) and two Korean ones (Euvax-B, LG Chemical Ltd., Korea, and HepavaxGene, Greencross Vaccine Corp., Korea) - in adolescents and young adults administered in three $10 \mu \mathrm{g}$ doses, corresponding to half the dose recommended for routine use in adults, using 0,1 , and 6 month or 0,1 , and 5-month schemes. The immunogenicity of three doses of other recombinant hepatitis B vaccines (including the Engerix-B vaccine from GlaxoSmithKline, England), administered intramuscularly and containing half the antigen amount indicated for adults $(0,1$, and 6 month scheme), has been demonstrated in children, adolescents and young adults $^{2,3,7,8,10}$ and their use has been recommended by the American Academy of Pediatrics ${ }^{1}$.

In the present study, in which the three cited vaccines were administered intramuscularly to hepatitis B-susceptible university students between the ages of 17 and 19 (three $10 \mu \mathrm{g}$ doses; 0, 1, and 5month scheme), immunogenicity was demonstrated for all of them, with seroconversion being obtained about one month after the third dose in more than $96 \%$ of the vaccinees: $96.2 \%, 98.6 \%$ and $96.5 \%$ for students receiving the Butang, Euvax-B and Hepavax-Gene vaccines, respectively. A similar seroconversion rate (97.6\%) was obtained with the Engerix- $B$ vaccine used for comparison. Among the students presenting seroconversion, $85.8 \%, 91.6 \%, 89.4 \%$ and $89.2 \%$ of those receiving the Butang, Euvax-B, Hepavax-Gene and Engerix-B vaccine, respectively, were considered to be good responders (anti-HBs $>100 \mathrm{mIU} / \mathrm{mL}$ about one month after vaccination was completed), with no significant difference between students receiving the four vaccines. The GMT of anti-HBs observed in the vaccinees was $1520.55 \mathrm{mIU} / \mathrm{mL}$. In a similar study in which three $10 \mu \mathrm{g}$ doses of Engerix-B were administered intramuscularly to individuals aged 11 to 19 years in a 0,1 , and 6-month scheme, the GMT was $1988.8 \mathrm{mIU} / \mathrm{mL}$ one month after application of the third dose ${ }^{10}$. The GMT for the Euvax-B and Engerix-B vaccines were higher than that obtained for the Butang vaccine, but this difference was 


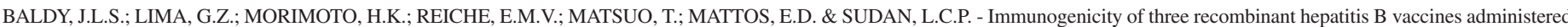
to students in three doses containing half the antigen amount routinely used for adult vaccination. Rev. Inst. Med. trop. S. Paulo, 46(2):103-107, 2004.

not observed when pairwise comparisons of these vaccines were performed. We are unable to explain why the GMT for the Butang vaccine was lower than that obtained for the other two vaccines.

No spontaneous adverse effects attributable to the application of any vaccine dose were reported by the vaccinated students.

In conclusion, the present results demonstrated a similar, highly satisfactory immunogenicity of the three recombinant hepatitis $B$ vaccines (Butang, Euvax-B and Hepavax-Gene) used in healthy 17- to 19-yearold individuals when applying the dose, route and scheme reported here, equivalent to that of the Engerix- $B$ vaccine, although the GMT of the anti-HBs obtained for the Butang vaccine was significantly lower than the GMT obtained for the Engerix-B and Euvax-B vaccines. The possibility to use half the vaccine dose in adolescents with the same efficacy and safety leads to a significant reduction in the cost of hepatitis $B$ vaccination and opens promising perspectives for the adoption of the same conduct in children (i.e., application of the three recombinant vaccines studied at half the dose routinely used for persons older than 19 years), considering that, with respect to two recombinant vaccines used at our institutions (Engerix-B, GlaxoSmithKline and Recombivax, Merck, Sharp \& Dohme), the reduced dose ( $10 \mu \mathrm{g}$ and $5 \mu \mathrm{g}$, respectively) is already indicated for newborns, children and adolescents ${ }^{1}$.

\section{RESUMO}

\section{Imunogenicidade de três vacinas recombinantes contra hepatite $\mathbf{B}$ administradas a estudantes em três doses contendo $50 \%$ da quantidade de antígeno usada rotineiramente para a vacinação de adultos}

Avaliou-se neste estudo a imunogenicidade de três vacinas recombinantes contra a hepatite B (HB), uma brasileira (Butang, do Instituto Butantan) e duas coreanas (Euvax-B, da LG Chemical Ltd. e Hepavax-Gene, da Greencross Vaccine Corp.), administradas a jovens com 17 a 19 anos, por via intramuscular, em três doses de $10 \mu \mathrm{g}$ (que correspondem a $50 \%$ da quantidade do antígeno contida na vacina usada rotineiramente em adultos), com intervalos de um mês entre a primeira e a segunda, e de quatro meses entre a segunda e a terceira doses. Foram vacinadas 316 pessoas nas quais não foi encontrado nenhum marcador sorológico de infecção pelo vírus da HB: 77 (24,4\%) com a Butang, 71 (22,5\%) com a Euvax-B, 85 (26,9\%) com a Hepavax-Gene e, para comparação, $83(26,2 \%)$ com a Engerix-B. A eficiência da vacina recombinante contra a hepatite $\mathrm{B}$ produzida pela GlaxoSmithKline (Engerix-B), em adultos jovens, na dose que usamos, já tinha sido comprovada em pesquisas anteriormente realizadas. Neste estudo, as taxas de soroconversão (anti-HBs $>10 \mathrm{mUI} / \mathrm{mL}$, cerca de um mês depois da terceira dose) obtidas com as vacinas Butang, Euvax-B, Hepavax-Gene e Engerix- $B$ foram semelhantes, iguais respectivamente a $96,2 \%, 98,6 \%$, $96,5 \%$ e $97,6 \%$. A frequiência de bons respondedores (anti-HBs $>100$ $\mathrm{mUI} / \mathrm{mL}$ ) foi também semelhante entre os que receberam as quatro vacinas $(85,8 \%, 91,6 \%, 89,4 \%$ e $89,2 \%$, respectivamente). A média geométrica dos títulos séricos de anti-HBs obtidos cerca de um mês depois da terceira dose, com essas vacinas, foi igual a 727,78 \pm 6,46 mUI/mL, 2.009,09 \pm $7,16 \mathrm{mUI} / \mathrm{mL}, 1.729,82 \pm 8,85 \mathrm{mUI} / \mathrm{mL}$ e $2.070,14 \pm 11,69 \mathrm{mUI} / \mathrm{mL}$, respectivamente. As médias geométricas dos títulos séricos de anti-HBs induzidos pela Euvax-B e pela Engerix-B foram maiores que a média geométrica do título sérico de anti-HBs induzido pela Butang $(\mathrm{p}<0,05)$; essa diferença não foi estatisticamente significativa quando se compararam, duas a duas, as outras vacinas. Não se registrou nenhuma queixa espontânea dos vacinados sobre eventos adversos que tivessem atribuído à aplicação de qualquer dose das quatro vacinas.

\section{ACKNOWLEDGEMENTS}

Many teachers and students from Universidade Estadual de Londrina (UEL) and Universidade Norte do Paraná (UNOPAR) directly or indirectly contributed to this study. We are especially indebted to Prof. Lúcio Mauro R. Ianta (UNOPAR), Allex Itar Ogawa, André Luiz Gonçalves Moreira, Fernando Vissoci Reiche, Hellen Yumi Yamaguti, André Clériston José dos Santos, André Luiz Minho, Doumit Camilios Neto, Gustavo Schimit, Kátia Kioko Yuahasi, Lissa Ito and Luís Fernando C. Reino (students of the Medicine or Pharmacy course of UEL), and Adriano Teixeira Gotinski, Andréia Viviane Bonesi, César Eduardo Moliani, Elisangela Gazola Bazzo, Elza Aparecida da Silva, Gislaine C. El Kadri Ibrahim, Juliana Aparecida Rossi, Leandro Feronato, Márcia Cristhine Faria, Maria Helena Mattosinho, Neuciléia G.C. Lorrenzzetti, Valnu Buzza Secco and Zenilde Clemente dos Santos (students of the Nursing course of UNOPAR).

\section{REFERENCES}

1. AMERICAN ACADEMY OF PEDIATRICS - Hepatitis B. In: PICKERING, L.K., ed 2000 Red Book: report of the Committee on Infectious Diseases. 25. ed. Elk Grove Village, American Academy of Pediatrics, 2000. p. 294.

2. BRYAN, J.P.; CRAIG, P.G.; REYES, L. et al. - Randomized comparison of 5 and 10 microgram doses of two recombinant hepatitis B vaccines. Vaccine, 13: 978-982, 1995.

3. CATANIA, G.; Di CIOMMO, V. \& CONCATO, C. - Vaccination against hepatitis B virus in children and adolescents in a pediatric hospital. Recent Progr. Med., 87: 271-274, 1996.

4. ELASHOFF, J.D. - nQuery Advisor® Version 2.0 User's Guide. Los Angeles, Dixon Associates, 1997.

5. FRANCIS, D.P.; HADLER, S.C.; THOMPSON, S.E. et al. - The prevention of hepatitis $B$ with vaccine. Report from the Centers for Disease Control multi-center efficacy trial among homosexual men. Ann. intern. Med., 97: 362-366, 1982.

6. HADLER, S.C.; FRANCIS, D.P.; MAYNARD, J.E. et al. - Long-term immunogenicity and efficacy of hepatitis B vaccine in homosexual men. New Engl. J. Med., 315: 209-214, 1986.

7. LEROUX-ROELS, G.; ABRAHAM, B.; FOURNEAU, M.; De CLERCQ, N. \& SAFARY, A. - A comparison of two commercial recombinant vaccines for hepatitis B in adolescents. Vaccine, 19: 937-942, 2000.

8. POOVORAWAN, Y.; PONGPUNLERT, W.; THEAMBOONLERS, A. et al. Randomized, single-blind comparison of the immunogenicity and reactogenicity of 20 micrograms and 10 micrograms doses of hepatitis B vaccine in adolescents. Southeast Asian J. trop. Med. publ. Hlth., 24: 255-259, 1993.

9. SAS INSTITUTE INC. - SAS/STAT user's guide, version 6. 4. ed. Cary, SAS Institute, 1989. v. 1.

10. SCHIFF, G.M.; SHERWOOD, J.R.; ZELDIS, J.B. \& KRAUSE, D.S. - Comparative study of the immunogenicity and safety of two doses of recombinant hepatitis B vaccine in healthy adolescents. J. Adolesc. HIth., 26: 12-17, 1995.

Received: 3 December 2003

Accepted: 5 March 2004 